\title{
Reviving Leviathan: Fiscal Federalism and the Growth of Government
}

\author{
Jonathan Rodden
}

\begin{abstract}
This article revisits the influential "Leviathan" hypothesis, which posits that tax competition limits the growth of government spending in decentralized countries. I use panel data to examine the effect of fiscal decentralization over time within countries, attempting to distinguish between decentralization that is funded by intergovernmental transfers and local taxation. First, I explore the logic whereby decentralization should restrict government spending if state and local governments have wide-ranging authority to set the tax base and rate, especially on mobile assets. In countries where this is most clearly the case, decentralization is associated with smaller government. Second, consistent with theoretical arguments drawn from welfare economics and positive political economy, I show that governments grow faster as they fund a greater portion of public expenditures through intergovernmental transfers.
\end{abstract}

For good or ill, fiscal decentralization is commonly thought to restrict the growth of government spending. Just as tax competition in an era of globalization is believed to place constraints on the revenue-raising capacity of governments, interjurisdictional competition within decentralized countries is believed to hamper government's ability to tax. For those who see government as a revenue-hungry beast, this is a welcome muzzle. For others, fiscal decentralization creates a worrisome "race to the bottom" that favors capital over labor and prevents governments from providing important collective goods. Pushing the normative and ideological questions aside, this article seeks to determine whether there is a link between decentralization and smaller government. At first glance the proposition seems doubtful: throughout the era of globalization and fiscal decentralization in the latter part of the twentieth century, public sectors have grown faster than private sectors around the world. On average, government expenditures accounted

The author wishes to thank Jim Alt, Jeff Frieden, Michael Hiscox, Per Pettersson-Lindbom, Antonio Rangel, Karen Remmer, Susan Rose-Ackerman, Anwar Shah, Ken Shepsle, Romain Wacziarg, Barry Weingast, Erik Wibbels, Justin Wolfers, and seminar participants at Harvard, Stanford, Texas A\&M, the University of Washington, and the World Bank for helpful comments. 


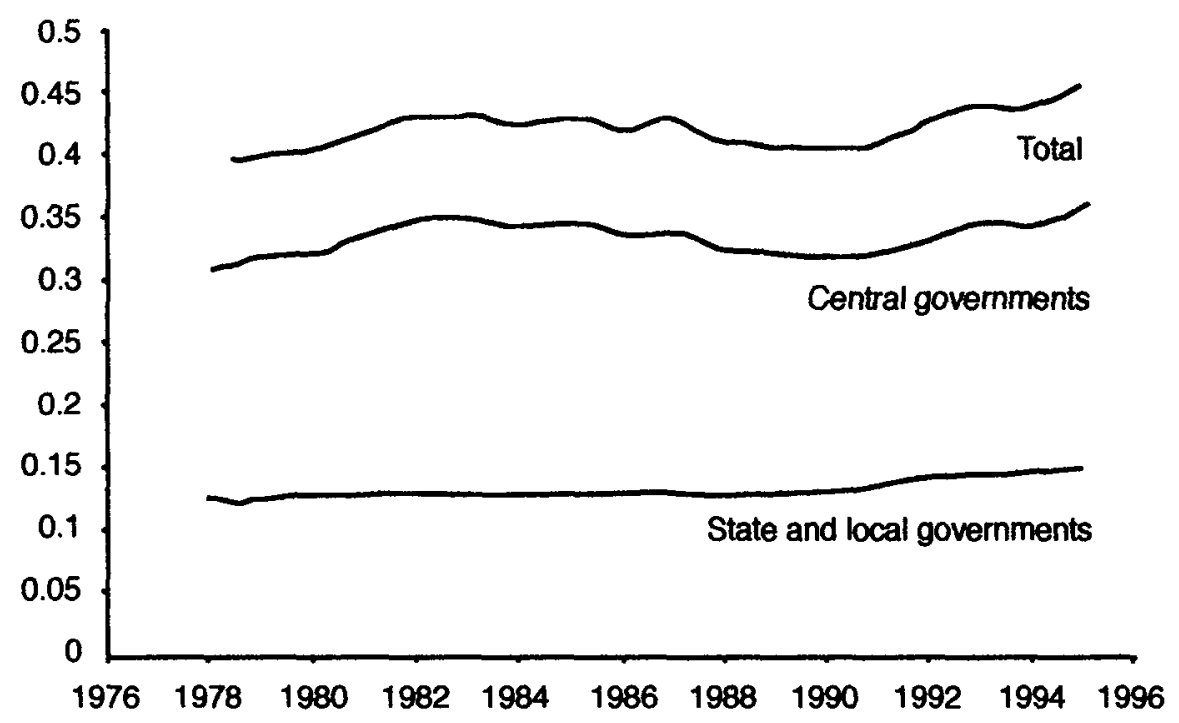

FIGURE 1. Government expenditure as share of GDP: Average for 29 countries

for around 39 percent of gross domestic product (GDP) in 1978, while by 1995 the average had increased to more than 45 percent for a sample of twenty-nine countries. (See Figure 1.) $)^{1}$ The growth has been particularly pronounced in the 1990 s.

Political scientists and economists have long sought to explain cross-national variation in levels and changes in government expenditure, often with mixed success. Although the academic literature focuses almost exclusively on central governments, the growth of state and local public sectors has been more pronounced in relative terms. This article directs attention to the balance of taxing and spending authority between central and subnational governments. In doing so, it returns to one of the oldest, and perhaps least successful, explanations of fiscal scale with a new perspective and new data. With their famous "Leviathan" hypothesis, Geoffrey Brennan and James Buchanan posit that "total government intrusion into the economy should be smaller, ceteris paribus, the greater the extent to which taxes and expenditures are decentralized."2 Depicting government as a revenuemaximizing Leviathan, Brennan and Buchanan argue that as long as some individuals and firms are mobile, fiscal decentralization forces governments to engage in tax competition, thus destroying Leviathan's monopoly on taxation and bringing

1. The data set used to create Figure 1 is introduced below. The twenty-nine countries are those for which a full time series from 1978 to 1995 was available (with the exception of a small number of missing observations that were interpolated to create the chart).

2. Brennan and Buchanan 1980, 15. 
government spending closer to the preferences of citizens. This argument dovetails with other less cynical suppositions that decentralization helps resolve an inherent agency problem between citizens and government.

This hypothesis was the subject of several empirical analyses in the 1980s. Though fiscal decentralization has been linked to lower government spending in some U.S., Canadian, and Swiss case studies, ${ }^{3}$ cross-national studies have been unable to demonstrate the hypothesized relationship. ${ }^{4}$ Indeed Wallace Oates has declared Leviathan a "mythical beast." 5 More recently, Ernesto Stein demonstrates that fiscal decentralization is actually associated with larger government in Latin America. ${ }^{6}$

However, this article argues that existing cross-national studies are insufficient to dispel the myth of Leviathan for two reasons. First of all, they employ crosssection averages or single-year snapshots. Thus they shed little light on the dynamic nature of decentralization and the growth of government-both of which are processes that unfold over time. Governance in many countries around the world is undergoing a major transformation since the 1980s. Cross-national empirical analysis demonstrates that a pronounced trend toward fiscal decentralization is linked with transitions to democracy-especially in large, formerly centralized countries. ${ }^{7}$ Using the same group of twenty-nine countries as Figure 1, Figure 2 shows that average state and local expenditure as a share of the total government sector has jumped from around 20 percent in 1987 to 32 percent in 1995. Thus it may be inappropriate to conduct empirical analysis as if all countries have reached a long-term equilibrium.

Second, until very recently, insufficient attention has been given to the precise institutional incentives created by different forms of decentralization. Above all, if decentralization is to have a constraining effect on the growth of government, it must occur on both the expenditure and revenue sides. In the vast majority of countries, however, increased state and local expenditures are funded primarily by grants, shared revenues, or other sources that are controlled and regulated by the center. Expenditure decentralization without corresponding local tax powers will not engender the tax competition that drives the Leviathan model, nor will it strengthen the agency relationship between local citizens and their representatives.

On the contrary, decentralization funded by "common pool" resources such as grants and revenue-sharing might have the opposite effect. By breaking the link between taxes and benefits, mere expenditure decentralization might turn the pub lic sector's resources into a common pool that competing local governments will attempt to overfish. Depending on whether funded by local or common pool

3. For example, Marlow 1988; Joulfaian and Marlow 1990; Grossman 1989; and Feld, Kirchgässner, and Schaltegger 2003.

4. For an exhaustive literature review, see Feld, Kirchgässner, and Schaltegger 2003.

5. Oates 1985.

6. Stein 1999.

7. See Panizza 1999; and Garrett and Rodden 2003. 


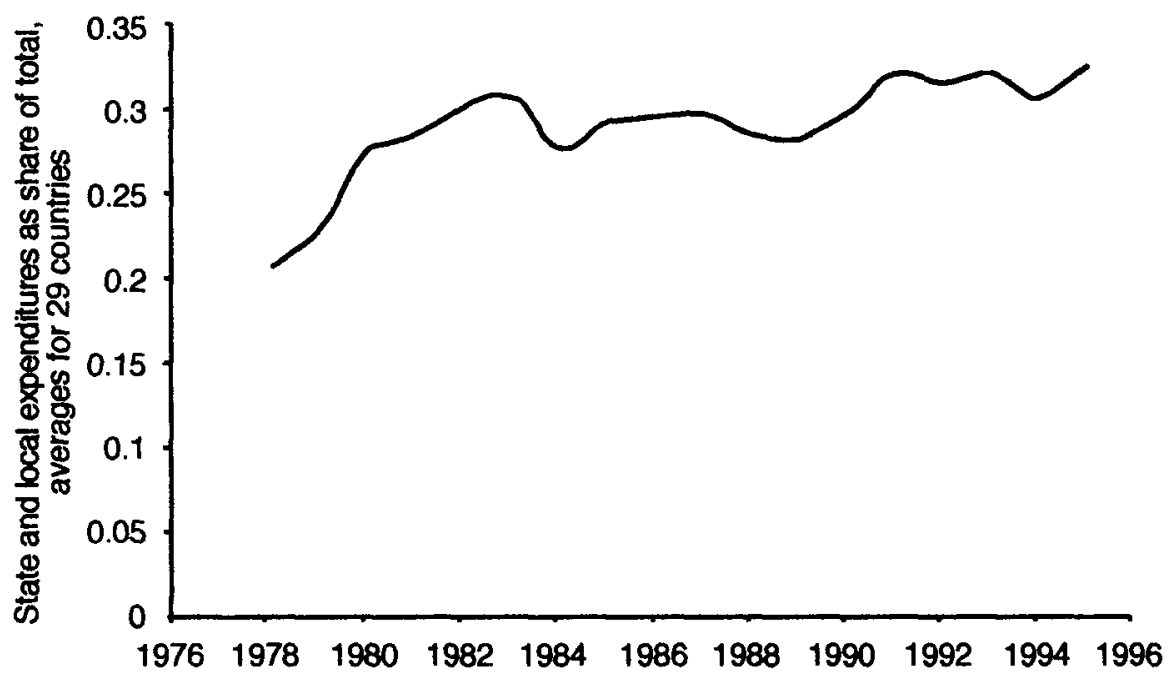

FIGURE 2. Fiscal decentralization, 29 countries

resources, decentralization might either retard or intensify the growth of government. Thus meaningful cross-national analysis requires data on transfers, revenuesharing, and local taxation that have heretofore not been examined.

This article reexamines the link between decentralization and the growth of government by addressing each of these problems. First, rather than concentrating exclusively on cross-country variation, I use panel data from a large group of countries spanning the years from 1978 to 1997 and use an error-correction setup to distinguish between transitory and long-term effects. Second, while expenditure decentralization is rather easy to measure across countries, subnational revenue autonomy is often swept under the rug in empirical research because it is conceptually complex and difficult to capture with cross-national data. As a corrective, I use a new data set that aims to pinpoint different aspects of subnational revenue autonomy.

The analysis demonstrates quite clearly that the effect of decentralization on government size is conditioned by the nature of fiscal federalism. Other things equal, decentralization (a relative shift in revenue from the center to the subnational governments), when funded by common pool resources, is associated with faster growth in overall government spending. In contrast, though the result relies on a smaller sample, decentralization that is funded by autonomous local taxation is associated with slower government growth.

The rest of this article proceeds as follows. The next section reviews and expands on existing theories linking decentralization and the size of government. The following section introduces the data set and empirical approach and then estimates a basic model exploring the conditional effects of decentralization on 
government size for a large sample of countries. The next section takes a closer look at the role of intergovernmental transfers by conducting separate analyses of central and subnational expenditures. While the global data set is useful for distinguishing between budgetary grants and various forms of "own-source" subnational revenue, it is poorly suited to examine state and local tax autonomy. The following section takes up this task with a smaller data set composed of countries from the Organization of Economic Cooperation and Development (OECD). The final section concludes and points out avenues for further research.

\section{Decentralization and Government Spending}

\section{Perspectives on the Size of Government}

A good deal of variation across countries in the size of government can be explained by examining the demands of citizens for public spending, which are to a large extent shaped by demographic and geopolitical factors. For instance, countries with a large portion of the society above or below the working age might have larger governments. According to popular interpretations of "Wagner's Law," the income elasticity of demand for government output is greater than unity, which leads to an increasing government share of total output as the economy expands. Additionally, the distribution of income before taxes and transfers within a country might shape the strength of demands for redistribution. ${ }^{8}$ Another literature examines the role of international trade and demands for government spending. ${ }^{9}$

Most models of government spending in the public finance tradition ignore the problem of preference aggregation-government is by assumption a benevolent despot that implements socially optimal policies. ${ }^{10}$ An alternative body of research in political economy examines government size as reflecting the optimal policy of the median voter. From either analytical perspective, government spending is viewed as ultimately "responsive" to underlying exogenous preferences. Yet another perspective views government spending as inherently "excessive," ing seriously the problem that demands by citizens for public spending are satisfied through an agency relationship that is fraught with difficulties. By no means does governmental policy necessarily represent the ideal point of the median voter. First of all, officials might abuse the natural information asymmetry between rulers and ruled and line their own pockets, leading to a larger public sector than

8. See, for example, Meltzer and Richard 1981; and Bolton and Roland 1997.

9. Cameron 1978 argues that small, open economies are more likely to develop strong labor movements and left-wing parties, and in turn these political conditions have been conducive to the growth of the public economy. Alternatively, Rodrik 1998 argues that increasing trade interdependence heightens insecurity, which in turn strengthens demands for public sector risk-sharing.

10. The classic text is Musgrave 1959.

11. A distinction between "responsive" and "excessive" explanations for the growth of government spending was made by Buchanan 1977. The distinction is explored empirically in the U.S. politics literature. See, for example, Berry and Lowry 1987. 
citizens would prefer. This has been the concern of the vast public choice literature on "rent-seeking," which departs from traditional public finance models and derives its analytical insights from assuming that governments maximize "perks" or "rents" that are at odds with the interests of voters. 12

Second, in the institutional political economy literature, politicians are viewed as primarily interested in reelection rather than rents or social welfare. Their electoral incentives, combined with the constraints of legislative institutions, might lead them to tax and spend more (or less) than the median voter would prefer. An important literature in this vein examines the possibility that representatives will seek to externalize the costs of government expenditures in their jurisdiction onto citizens of others, turning public revenue into a common pool that is quickly overfished. ${ }^{13}$ As a consequence of the incongruence between spending and taxation that arises when geographically targeted expenditures are funded with general taxation, representatives misperceive the costs of spending and demand an "excessive" amount, because they take into account all of the benefits but only consider the share of taxes that falls on their constituents. This might lead to spending that exceeds the socially optimal amount. According to Buchanan and Wagner, ${ }^{14}$ a further problem is that voters do not fully understand the relationship between current deficits and future taxes - they simply reward spending and punish taxation. Politicians with electoral motivations face incentives to take advantage of their "fiscally illuded" voters with excessive deficit-financed spending, especially in election years.

In a more recent literature, Persson and Tabellini argue that majoritarian-as opposed to proportional-elections increase competition between parties by focusing it in some key marginal districts, which leads to policies favoring targeted redistribution at the expense of broad public goods and social insurance programs. ${ }^{15}$ They also argue that presidential regimes encourage more intense competition than parliamentary regimes, which leads to fewer rents, less redistribution, and smaller government in the former. ${ }^{16}$

Such institutional arguments hold constant demands for expenditure-as determined by demographics, economic growth, trade, and so on-and examine the role of institutional incentives structuring the agency relationship between citizens and politicians. One common thread in these arguments is the notion that institutions can strengthen or undermine the ability of citizens to discipline government's "natural" tendency toward excess. If one assumes that the natural tendency of government is to overspend, improved oversight should lead to smaller

12. An engaging debate between these perspectives is presented in Buchanan and Musgrave 1999.

13. See Buchanan 1977; and Weingast, Shepsle, and Johnsen 1981.

14. Buchanan and Wagner 1977.

15. Persson and Tabellini 2000, chaps. 8-9. Milesi-Ferretti, Perotti, and Rostagno 2001 derive rather similar predictions from a model focusing on how electoral institutions affect voters' strategic delegation.

16. Persson and Tabellini 2000, chap. 10. Empirical support is provided in Persson and Tabellini 2002. 
government. But in more recent literature, institutions affect the size of government in ways that do not require rent-seeking assumptions. Institutions might systematically provide career-oriented politicians with incentives to overfish the common revenue pool, or to favor one group over another-rural over urban dwellers, residents of marginal or "swing" districts, the middle class, or perhaps capital over labor. In this view, institutions that favor voters with strong preferences for public goods or redistribution should be associated with larger government.

\section{Decentralization as a Constraint on Leviathan}

Each of these intellectual traditions has posited a link between fiscal decentralization and the size of the public sector. First, to the extent that fiscal decentralization brings government "closer to the people" and facilitates a better match between local preferences and local policies, it may enhance the information available to voters about government activities and put them in a better position to sanction poor performance or rent-seeking, perhaps even clarifying the tax-benefit link and reducing the problem of fiscal illusion. ${ }^{17}$ Besley and Case argue that "benchmark competition" allows voters in adjacent jurisdictions to compare directly tax prices paid and public goods received, assessing whether decentralized governments are wasting or stealing resources. ${ }^{18}$ If one assumes that a component of tax revenue is always stolen or wasted, having a more efficient jurisdiction next door might put limits on the size of that component.

However, such argument linking decentralization and enhanced accountability require hefty assumptions about the quality of the local democratic process and the information available to voters. Under plausible conditions, decentralization is just as likely to lead to capture by local interest groups and increased corruption. ${ }^{19}$ Moreover, given the limited resources that citizens have to invest in monitoring the fiscal activities of government, it is plausible that they are better equipped to monitor only one level of government - the central government-and any decentralization of spending or taxing authority will undercut monitoring. ${ }^{20}$ Taking a different perspective, Wallace Oates questions the link between better monitoring and smaller government, pointing out that if decentralization enhances oversight of government, voters might actually demand more spending, knowing that less of it will be dissipated in rents. ${ }^{21}$ In short, the arguments asserting a relationship between decentralization, improved accountability, and smaller government are driven by rather strong assumptions about the preferences of voters and politicians. Moreover, the logic of each of these arguments requires not only the

17. For a welfare economics perspective, see Oates 1972 . For a public choice perspective, see Buchanan 1995.

18. Besley and Case 1995.

19. See Bardhan and Mookherjee 2000; Rodden and Rose-Ackerman 1997; and Treisman 2001.

20. Franzese 2001 .

21. Oates 1985 gives credit to John Wallis for formulating this argument. 
decentralization of expenditure authority but also tax authority. A stronger taxbenefit link, clearer information, stronger incentives for monitoring, and benchmark competition will not arise if taxation remains centralized.

In addition to strengthening monitoring, tax decentralization might help resolve the common pool problem. Consider a "fiscally centralized" system where local public goods are funded through general taxation and allocated in a central legislature featuring district-based representation. In the basic common pool setup, each district decides on the supply of public goods, and the centralized tax rate is residually determined. The common pool problem arises because each district internalizes the benefit of its public goods but internalizes only a fraction of the social marginal cost of higher taxes. Spending should be lower in an alternative decentralized scenario in which all public goods must be funded at the district level by local taxes. However, the existence of the common pool problem in practice depends a great deal on the specifics of legislative organization ${ }^{22}$ and can be rather easily circumvented by determining the size of the budget before addressing allocation, or by delegating authority to a strong finance minister or president. ${ }^{23}$ The presence of a legislative common pool problem is very difficult to pinpoint using cross-national data, so it is difficult to identify the countries in which fiscal decentralization might solve it.

The literature on tax competition-which spans the perspective of public choice, public finance, and institutional political economy-provides the most unambiguous link between fiscal decentralization and smaller government. Brennan and Buchanan made the argument that under decentralization, government's quest for rents and revenue is undermined by the need for jurisdictions to compete with one another for mobile sources of revenue. ${ }^{24} \mathrm{~A}$ much earlier version of this argument was made by Friedrich von Hayek, who laid out a vision of "interstate federalism" in which "the methods of raising revenue would be somewhat restricted for the individual states. Not only would the greater mobility between the states make it necessary to avoid all sorts of taxation that would drive capital or labor elsewhere, but there would also be considerable difficulties with many kinds of indirect taxation." 25 In this "excessive government" public choice perspective, tax competition reduces rents and, hence, a smaller public sector enhances overall welfare.

A similar connection between tax competition and smaller government has also been established in public economics models with benevolent despots in an opti-

22. Inman and Rubinfeld 1997 contrast "minimum winning coalition" legislatures and "universalistic" legislatures. The latter are more likely to demonstrate the common pool problem. Moreover, weak or fragmented coalition governments may find it difficult to withstand spending pressure, as in Ratts $\emptyset$ 2000. A less political model is presented by Persson and Tabellini 1994, in which subnational governments bribe the central government to provide them with a larger share of common resources.

23. See Von Hagen 1998.

24. Brennan and Buchanan 1980.

25 . Hayek 1939,$270 ; 1948,260$. This argument has recently been extended to explain commitments to the preservation of markets. See, for example, Weingast 1995. 
mal taxation framework. ${ }^{26}$ But this perspective often views the result as pushing public spending away from the social optimum rather than toward it. Tax competition is viewed as a problem to be solved with central government intervention. Not surprisingly, the debate has taken an ideological tone, often turning into arguments about the appropriateness of radically different optimistic and cynical assumptions about the motivations of politicians.

However, one need not make blunt assumptions about benevolent or malevolent politicians to derive a link between tax competition and small government. The same result can be obtained by adopting an institutional political economy perspective and analyzing a conflict between owners of relatively mobile and less mobile assets. Specifically, decentralized capital taxation implies not only a shift in the burden of taxation toward owners of immobile assets, but under very plausible conditions it also implies smaller government.

Consider a closed, centralized country with $n$ identical districts, where each district consists of individuals divided into cleavages based on the relative mobility of the assets from which they receive their income (labor versus capital, land owners versus renters, farmers versus light manufacturing). Also assume that these moving costs are exogenous and that - especially plausible for labor and capitalthe owners of relatively immobile assets outnumber the owners of mobile assets (by the same margin within each district and in the country as a whole). In this centralized system, the level of spending on public goods, $G^{c}$, is determined by the national median voter - an owner of relatively immobile assets - and distributed to the districts according to population. In this scenario, the national median voter will choose to externalize as much of the fiscal burden as possible onto owners of more mobile assets. In the extreme case, the tax rate on mobile assets is set at the revenue-maximizing rate at the top of the Laffer curve, $T_{m}^{c}$, while the rate on immobile assets, $T_{i}^{c}$, is set at zero. Ignoring deficit finance, the level of public expenditure is

$$
G^{c}=M\left(T_{m}^{c}\right)+I\left(T_{i}^{c}\right)
$$

where $M$ is the value of mobile assets and $I$ is the value of immobile assets. Because $T_{i}^{c}$ is zero, public expenditures are simply equal to $M\left(T_{m}^{c}\right)$.

Contrast this with a decentralized setting in which the same districts are independent jurisdictions who set their own tax rates and choose their own levels of spending. Spending in the decentralized system, $G^{d}$, is a summation of the level chosen by each individual jurisdiction. The median voter within each jurisdiction still prefers to externalize the same portion of the fiscal burden onto owners of mobile assets, but the latter are now free to shop around for jurisdictions that can offer them a lower tax rate. Unless the jurisdictions can form a cartel, in the 
presence of fiscal competition it will be impossible for any jurisdiction to charge $T_{m}^{c}$. The less mobile within each jurisdiction must compete with those in other jurisdictions for mobile individuals and firms to tax, and $T_{m}^{d}$ falls to the equilibrium value in the intergovernmental marketplace. Especially when the relevant distinction is between capital and labor, labor will be forced to lower capital taxation to preserve jobs. The only way to maintain the same level of public spending as in the centralized scenario is for each jurisdiction to raise $T_{i}$ to the point where $I\left(T_{i}^{d}\right)=M\left(T_{m}^{c}-T_{m}^{d}\right)$. Stripped of the power to externalize the funding of public goods onto the mobile, owners of immobile assets must now choose only the level they can afford by taxing themselves. If they choose to make up the full difference, decentralization would merely entail a shift in the tax burden from the mobile to the immobile. In the more likely event that the immobile majority demands higher levels of expenditure in the centralized scenario (where the tax burden falls on concentrated owners of mobile capital), tax decentralization implies that expenditures fall below the level that the median voter would select in a world where the exit power of the mobile minority is limited. ${ }^{27}$

In sum, whether one travels the roads of welfare economics, public choice, or institutional political economy, one arrives at the same hypothesis, though with radically different normative interpretations: other things equal, decentralized taxation-in particular capital taxation-restricts the size of government. Though decentralized taxation might reduce agency costs as well, the simplest and most compelling logic involves limitations on the taxation of mobile capital.

\section{Decentralization as a Boon for Leviathan}

The intergovernmental tax competition literature resonates with theories of globalization and public spending. A familiar logic holds that as countries open capital markets and compete for foreign investment, governments are forced to reduce capital taxation and ultimately either shift the burden of taxation onto the immobile or reduce public expenditures. Even if the median (presumably immobile) voter prefers higher expenditures in a world of perceived increasing economic insecurity and governments are primarily interested in making voters happy, the constraints of competing for mobile capital may force government expenditures below this ideal point.

There is a very important difference, however, between global tax competition and fiscal decentralization within countries-the presence of a central government "Leviathan." No system of fiscal federalism is anarchic. Even in the most decentralized fiscal systems, such as Canada and the United States, the activities of the

27. Again, the empirical prediction is clear, but the normative implication is not. Persson and Tabellini 2000 , chap. 6 , provide a more complete dynamic model of distributive battles between capital and labor in the context of mobility with a similar result. They point out that even though equilibrium expenditure is pushed below the ideal point of the median voter, tax competition might nevertheless be socially desirable because it lends credibility to a policy of nonconfiscatory capital taxes. Without tax competition, the government cannot commit ex ante not to over-tax capital after it has accumulated. 
central government are interdependent with those of the subnational governments. In more centralized systems, such as the United Kingdom or Norway, governments regulate virtually every aspect of local taxation, expenditure, and borrowing. In all systems of fiscal federalism, subnational governments are agents not only of local citizens, but also - and in some cases much more so-agents of the central government. The vision of unconstrained tax decentralization in the simple decentralization scenario above is unrealistic. In addition to direct regulation, central governments alter the incentives of subnational governments through intergovernmental grants.

Such grants can affect the link between fiscal decentralization and the size of government in several ways. First of all, in the traditional public economics literature on fiscal federalism, grants are made by benevolent central governments primarily to internalize externalities and solve coordination problems. Under the reasonable assumption that a shift toward greater local government resources and autonomy leads to increased interjurisdictional externalities and coordination problems, the demand for corrective intergovernmental transfers will increase. Decentralization funded through grants might also be associated with a larger public sector if something exogenous, such as a baby boom or terrorist threat, increases the demand for local public goods, such as primary education or emergency preparedness, which in many countries are funded through general taxes that are transferred to states, towns, or districts. In fact, the global trend toward fiscal decentralization has occurred almost exclusively through increased grants and shared revenues rather than the devolution of tax authority. In newly decentralizing developing countries, this fact is shaped in part by the challenges of developing effective systems of local tax administration in the context of poverty, regional inequality, and administrative underdevelopment.

It is relatively clear from public economic theory that increased grants should be associated with increased subnational expenditures. In a model that focuses on the indifference of the median voter between spending income on public and private goods, Bradford and Oates posit that the effect of a grant can be equivalent to that of a reduction in taxes to individual taxpayers. ${ }^{28}$ When grants go up, the median voter will demand some increase in the consumption of private goods. However, unless one makes the extreme assumption that the income elasticity of demand for public goods is zero, increased grants should have a positive effect on spending by local governments. Moreover, a massive empirical literature spanning many decentralized countries shows not only that increased grants have positive effects on local expenditures, but in contrast to the "equivalence theorem," very little if any of the windfall is absorbed by tax reductions. Though the underlying logic is poorly understood, the "flypaper effect"-the observation that money "sticks where it hits"-is one of the most enduring empirical results in public economics. ${ }^{29}$ 
Existing literature provides much less insight into what happens to the budget of the central government when it increases grants. Do increased intergovernmental transfers supplement or replace existing central government expenditures? The latter is possible but seems unlikely. For instance, if an increase in grants is motivated by demands to solve an interjurisdictional externality problem or respond to rising demands for local public goods, there is no compelling reason to believe that demands for other forms of central government expenditure will wane. In short, though somewhat ambiguous, one might expect that other things equal, increasing reliance on intergovernmental grants will be correlated with larger government purely from a welfare economics perspective, without the introduction of rentseeking and electoral motivations.

But the adoption of a public choice or institutional political economy perspective makes the case much stronger. In practice, intergovernmental grants are not distributed by benevolent central planners, but rather by strategic politicians. Political incentives might create a distributive logic in grant programs that puts upward pressure on the size of government. Governments will not compete if they do not tax, or if fiscal equalization schemes guarantee them a flow of revenue that undermines their incentives to exert tax effort. ${ }^{30} \mathrm{In}$ fact, some public choice scholars view intergovernmental grants as cartel-like collusion among subnational governments to avoid the discipline of tax competition. ${ }^{31}$ Alternatively, revenue-sharing and transfer schemes might originate as attempts by less mobile groups, such as farmers and laborers, to exert voice at the center to avoid the deleterious (for them) effects of tax competition. Contrary to the simple scenario described above, even in the most decentralized countries, the central government reserves the right to tax mobile capital. This gives the "losers" from tax competition a chance to mobilize at the central level. If the power to set tax rates on mobile capital is devolved to lower-level governments, immobile asset owners might attempt to raise the federal tax rates on mobile capital to make up for the difference between $M\left(T_{m}^{c}\right)$ and $M\left(T_{m}^{d}\right)$, distributing these revenues through grants or revenue-sharing programs.

Second, returning to arguments about agency and monitoring, decentralization might actually distort information and weaken oversight if funded by intergovernmental grants rather than local tax effort. The involvement of two or three levels of government in funding, legislating, and implementing the same policies makes it difficult for voters to identify and punish waste and rent-seeking. Moreover, the center-local agency relationship is laden with adverse selection problems, because local governments have incentives to exaggerate costs and distort information when reporting to the center to receive larger transfers. Decentralization funded by increased transfers might muddle rather than clarify the link between taxes and benefits, which increases the likelihood of fiscal illusion. In addition to the problems

30. Careaga and Weingast 2000 refer to this as the "fiscal law of 1 over $n$ " in which revenuesharing programs undermine incentives for fiscal effort among recipient governments.

31. See Grossman 1989; and Grossman and West 1994. 
of complexity and opacity, intergovernmental grants create the appearance that local public expenditures are funded by nonresidents, causing voters to demand an excessive amount. ${ }^{32}$ In this context, legislators face strong incentives to overfish the common revenue pool as described above, leading to larger government if the budget process and organization of the legislature do not place firm limits on overall expenditures. Rather than ameliorating the common pool problem, decentralization funded by increased transfers might exacerbate it.

The problem is only compounded if local governments have access to independent borrowing, in which case the fiscal illusion associated with intergovernmental transfers can soften the local budget constraint and create an intergovernmental moral hazard problem. For a variety of reasons, central governments might find it difficult to commit to a policy of ignoring self-induced subnational fiscal crises, especially when these threaten to undermine the stability of the banking system, the macroeconomy, and the country's credit rating, not to mention the government's reelection chances. ${ }^{33}$ Heavy dependence on intergovernmental transfers increases the likelihood that central government officials will be held politically responsible for local service reductions or defaults. If local tax autonomy is limited and subnational governments are dependent on a large and increasing flow of finance from the common revenue pool to fund public expenditures, voters and creditors are likely to perceive an implicit bailout guarantee. ${ }^{34}$ This encourages local governments to borrow aggressively rather than adjust in the face of revenue shortfalls, attempting to externalize the costs of adjustment onto other jurisdictions. If cofinancing obligations undermine the center's commitment to ignore subnational fiscal woes, the longterm result will be higher expenditures at every level of government.

Though the normative implications diverge widely, one can derive the same empirical prediction from public economics, public choice, or institutional political economy: decentralization funded by intergovernmental grants from the common revenue pool will be associated with higher overall government spending.

\section{The Conditional Effect of Fiscal Decentralization on the Growth of Government}

Depending on the precise nature of political and fiscal incentive structures, fiscal decentralization might lead either to a smaller or larger public sector. Some variant of the "Leviathan" hypothesis should hold if a shift toward greater local government expenditure as a share of the total public sector is driven by a shift toward greater local tax autonomy. More precisely, decentralization should lead to smaller government if it explicitly shifts taxation-especially of mobile assets-from the

32. For an overview of concepts and measurements of fiscal illusion and a literature review, see Oates 1991. For a theoretical application to intergovernmental grants in particular, see Oates 1979.

33. See Rodden, Eskeland, and Litvack 2003.

34. See Rodden 2002, 2003; and Eichengreen and Von Hagen 1996. 
center to the subnational governments without a corresponding increase in central government taxation. On the other hand, the common pool hypothesis holds that if decentralization is funded by intergovernmental transfers or revenue-sharing schemes, it will be associated with a larger public sector.

\section{Previous Studies}

In the first study to use cross-national evidence to assess the Leviathan hypothesis, no distinction was made between the Leviathan and common pool hypotheses, and the measures of decentralization were quite simple - subnational revenue and expenditure shares of the total public sector. ${ }^{35}$ While Wallace Oates found no significant relationship, more recent work by Ernesto Stein and his associates finds a significant positive relationship between decentralization (measured in a similar way) and the size of government. ${ }^{36}$ They introduce intergovernmental grants into their analysis and find that, consistent with the common pool hypothesis, this relationship is compounded by dependence on intergovernmental transfers. Moreover, the Stein study demonstrates the advantage of using a small data set with cross-section averages; it allows one to focus on specific aspects of the intergovernmental system-such as the procedures through which grants are formulated and distributed - that might help shed further light on the common resource problem.

However, this empirical approach does not allow for the possibility that the relationship between decentralization and government spending might be reversed in those countries where decentralized spending is funded primarily by local taxes. In other words, it only tests a version of the common pool hypothesis and ignores the Leviathan hypothesis, though the two are not mutually exclusive. Thus in the analysis that follows, I attempt to improve on previous attempts to distinguish between decentralization that is funded by grants and "own-source" local revenue.

Perhaps the most serious disadvantage of previous empirical approaches has been the exclusive reliance on cross-section rather than diachronic variation. ${ }^{37} \mathrm{~A}$ more convincing test of the relevant hypotheses would examine both cross-national and within-country changes in the nature of fiscal decentralization that might speed, retard, or perhaps even reverse the growth of the public sector. Thus in the analysis that follows, I use a data set composed of yearly observations from the period from 1978-97 for forty-four countries-all of the countries and years for which sufficient time-series data are available, along with smaller subsamples. These include countries from every continent and level of development. Descriptive statistics and further details about the dataset are provided in the Appendix.

35. Oates 1985.

36. See Inter-American Development Bank 1997; and Stein 1999.

37. For a critique of cross-country regressions on government size without a time-series component, see Berry and Lowery 1987. 


\section{Dependent Variables}

The dependent variable for the regressions presented below is a measure of total public-sector expenditure as a percent of GDP. This is calculated for each countryyear by taking the sum of expenditures of the central, state, and local governments from the IMF Government Finance Statistics (GFS) ${ }^{38}$ and dividing by GDP (from the IMF's International Finance Statistics). ${ }^{39}$ The regressions in the next section also examine central and subnational expenditure shares of GDP separately.

\section{Main Independent Variables}

For the purposes of this article, total government revenue can be broken down into three types:

- Central revenue: Revenue that is raised and spent by the central government.

- Grants: Revenue that is raised by the central government and transferred to lower-level governments.

- Own-source subnational: Revenue that is raised and retained by lower-level governments themselves.

Fiscal decentralization is defined as a decline in central revenue relative to grants and "own-source" subnational revenue. While critically important, the distinction between grants and "own-source" revenue is often difficult to make in practice. Fortunately, the GFS distinguishes between "grants" and various forms of "ownsource" subnational revenue (local taxes, user fees, interest income, and so on). However, the residual category of "own-source" revenue is not necessarily a proxy for tax autonomy, because it fails to distinguish between tax revenues that are legislated and collected locally and those that accrue to the subnational governments automatically through revenue-sharing schemes. As a result, "own-source" revenue measured with the GFS may not be ideal for a cross-country analysis of public spending, because it does not fully capture the directness of the tax-benefit link or the likelihood of tax competition, both of which may be undermined by revenue-sharing programs or central regulation of local tax rates or bases.

Nevertheless, the distinction is important, and these data are quite valuable for the analysis of changes over time within countries. The GFS classification "grants" refers to explicit intergovernmental transfers that appear in the yearly budget but exclude recurring automatic distributions of shared taxes. Thus the grants reported

38. To avoid double-counting intergovernmental transfers (in the expenditures of the center and again at subnational levels), grants are subtracted out.

39. Surprisingly, all of the existing papers on globalization and the size of the public sector only measure central government spending (for example, Rodrik 1998; Garrett 2001; and Quinn 1997). The measures used in these studies are virtually identical to the central government component of the variable used here (correlation .97), but these studies severely underestimate the size of the public sector in the United States, Canada, Switzerland, and several other highly decentralized countries. 
by the GFS reflect the subnational revenue flows that are most subject to central government discretion-arguably the type of transfer that is most likely to create a common resource dilemma or encourage bailout expectations. Hence grants to lower-level governments, taken as a percent of total public sector revenue at all levels of government (center + state + local), are a useful source of variation over time within countries to test the common pool hypothesis. This variable captures the effect of a shift in the balance of revenue from the center to the subnational governments that is funded by budgetary grants. The second independent variable, "own-source" subnational revenue as a share of total revenue, captures the effect of a relative shift that is funded by taxes, user fees, revenue-sharing, and other types of revenue. Taken together, these two variables capture the effects of two different types of fiscal decentralization. ${ }^{40}$

\section{Estimation Technique}

To assess properly the effects of different types of decentralization on the size of government, it may be important to distinguish between short-term and long-term dynamics. The arguments relating decentralization to the size of government are best understood as pertaining to long-term equilibria. A variety of factors might cause a transitory one-year increase in subnational revenue as a share of the total without altering any of the incentives discussed above. Rather, to shed light on the long-term "moving equilibrium," an error-correction model (ECM) is attractive. By estimating changes in the dependent variable and including both changes and lags of the independent variables, it is possible to distinguish between short-term or transitory effects of different types of decentralization, and the effects of a longterm moving equilibrium level. The error-correction version of the basic model can be expressed as follows:

$$
\begin{aligned}
& \triangle L O G \text { GOVERNMENT SIZE }{ }_{i n} \\
& =\beta_{0}+\beta_{1} \text { LOG GOVERNMENT SIZE } E_{\mathrm{it}-1} \\
& +\beta_{2} \Delta L O G \text { GRANTS/TOTAL REVENUE } \\
& +\beta_{3} \text { LOG GRANTS/TOTALREVENUE } \mathrm{it}_{\mathrm{it}-1} \\
& +\beta_{4} \Delta \text { LOG OWN-SOURCE SUBNAT.REV./TOTAL REVENUE } \mathrm{it}_{\mathrm{it}} \\
& +\beta_{5} \text { LOG OWN-SOURCE SUBNAT.REV./TOTAL REVENUE } \mathrm{it}_{\mathrm{it}-1} \\
& +\Sigma C O N T R O L S+\Sigma C O U N T R Y \text { DUMMIES }+\varepsilon
\end{aligned}
$$

40. In a preliminary set of regressions (not reported), I confirm the finding of Oates 1985 that when measured simply as subnational expenditures or revenues as a share of the total, decentralization has no significant effect on government size. 
The coefficients of interest are $\beta_{3}$ and $\beta_{5}$, which estimate long-term effects. ${ }^{41}$

Im-Peseran-Shin and Levin-Lin tests for unit roots lead to the conclusion that the two decentralization variables are stationary. Total public expenditure as a share of GDP exhibits a pronounced upward trend, but tests conclude that the first differences used as the dependent variable are stationary.

It is important to include fixed country effects for several reasons. First of all, even with a large and carefully selected matrix of control variables, it is likely that without the country dummies, the analysis would suffer from substantial bias owing to omitted variables that help determine long-term cross-country differences in levels of public expenditure. Moreover, I have argued that the GFS distinction between grants and "own-source" revenue is more useful within countries over time than across countries, so it is prudent to focus on long-term withincountry changes with a fixed-effects model. ${ }^{42}$

There is considerable debate about the appropriate estimation technique for such a model. The results presented below are from models that use the panel-corrected standard errors to deal with heteroskedasticity. However, the presence of the lagged level of the dependent variable can bias the fixed-effects ordinary least squares (OLS) estimator even if the error term is not correlated over time. In panels where the timeseries dimension is long, this bias may not be severe. The data set used in this section does cover a reasonable number of years (1978-97), but in order to include as many countries as possible (including some in Sub-Saharan Africa and Central and Eastern Europe, for whom data were available only for shorter periods), the panels are unbalanced and include a smaller number of years for some countries. Thus I have explored (1) subsamples that allow for balanced panels and a long time-series dimension, and (2) a variety of alternative estimation techniques-described below-but each yields very similar results to the results reported in the tables.

\section{Control Variables}

The models presented below include a matrix of control variables suggested by the existing literature on the growth and size of government. For most of these variables as well, it is useful to examine separately the effects of first differences and lagged levels. First, I include several variables that might affect the demand for public expenditures. To take account of government attempts to smooth tax rates over time or conduct counter-cyclical policy in the short-term, or the possibility of the long-run "Wagner's law" effect, I include both changes and lagged levels of real GDP per capita (purchasing power parity in international dollars). ${ }^{43}$ Demands for welfare spending might be driven by demographics, so I include

41. Logarithmic transformations of the fiscal variables are used because they improve the fit of the model and facilitate interpretation of coefficients.

42. In addition, a Hausman test rejects the random effects estimator, and the country dummies are jointly significant.

43. Taken from Penn World Tables. Data set available at 〈http://pwt.econ.upenn.edu〉. Accessed 7 July 2003. 
changes and lagged levels of population and the "dependency ratio"of the society above or below the working age. ${ }^{44}$ Country size (square kilometers) is included in some of the regressions as well. To control for the arguments discussed above about trade and capital account openness, I use changes and lagged levels of trade/GDP ratios to capture the international integration of national goods and services markets. In addition, capital account openness is a dummy variable from the IMF's annual Exchange Arrangements and Exchange Restrictions describing whether countries impose significant restrictions on capital account transactions (coded as " 0 ") or not ("1" = open).

Next, I include variables that control for the effects of institutions. Demands for redistribution may be harder to ignore in more democratic countries, but, on the other hand, it is plausible that citizens have better control over rent-seeking politicians in democracies. To deal with these possibilities, I include changes and lagged levels of Gurr's 20-point scale of democracy (taken from the Polity 98 Data Set). In addition, there is a large literature linking divided government (in presidential systems) and fragmented governing coalitions (in parliamentary systems) to "wars of attrition" and budget deficits. ${ }^{45}$ The implications of such political fragmentation for fiscal scale are less clear, but it seems plausible that "wars of attrition" in systems with large debt levels create a status quo bias in expenditures. A measure of executive and legislative fragmentation that bridges the parliamentary-presidential divide by incorporating both institutional and partisan veto players is included in the World Bank's Database of Political Institutions (DPI). ${ }^{46}$ If the effect of political fragmentation on expenditures is through slowed adjustment, this variable should be interacted with the lagged debt level. Because debt data are unavailable for many countries, the central government's lagged deficit/GDP ratio is used instead. To control for the possibility of electoral spending cycles, I include a dummy variable for federal executive election years, also taken from the DPI. Next, given the arguments of Persson and Tabellini about presidential versus parliamentary regimes, I include a variable from the DPI that takes the value zero for presidential systems, one for systems with assembly-elected presidents, and two for parliamentary systems. Finally, to control for the effect of government partisanship, I include a variable, also from the DPI, that takes the value -1 when the executive is controlled by the left, 0 for the center, and 1 for the right. ${ }^{47}$

44. Taken from World Development Indicators 2000.

45. See Alesina and Drazen 1998; and Roubini and Sachs 1989.

46. The variable, called "CHECKS $2 \mathrm{~A}$ " is the sum of 1 for the president and 1 for each legislative chamber in presidential systems. Legislative chambers are not counted if elections are noncompetitive, or if list proportional representation (PR) is used and the president controls more than 50 percent of the body. For parliamentary systems, it is the sum of 1 for the prime minister and 1 for each coalition party. The number is reduced by 1 if closed lists are used and the prime minister is in the coalition. For noncompetitive elections, the number of coalition parties is reduced to zero. Finally, the index is augmented by 1 for every veto player whose left-right orientation is closer to the opposition's than to the average of the rest of the government.

47. All of the models presented below were also estimated with a full matrix of year dummies, but these were never jointly significant, nor did they affect the substance of significance of the results. 
TABLE 1. Estimates of changes in the size of government

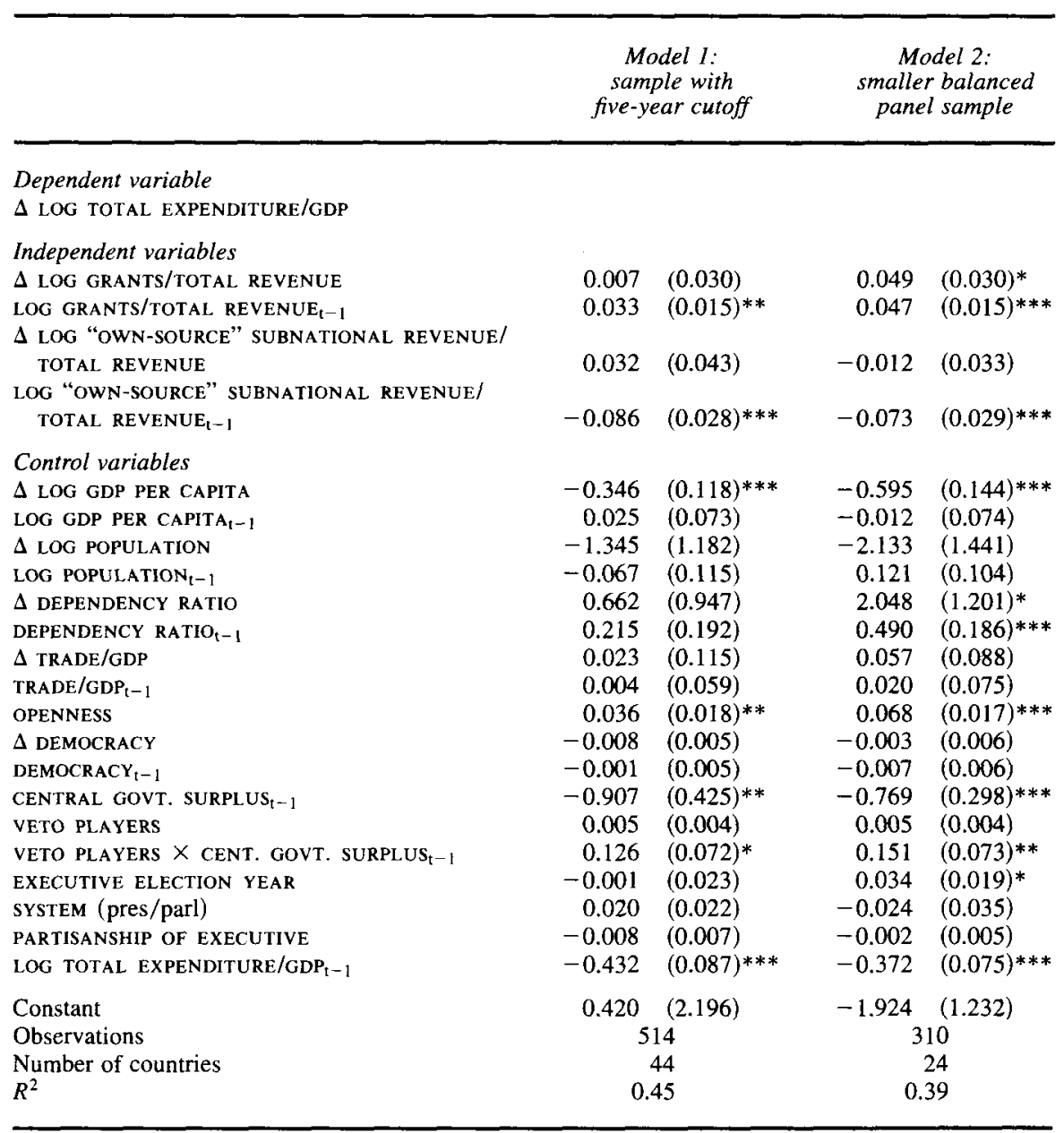

Note: Panel-corrected standard errors in parentheses. Fixed effects models, coefficients for country dummies not shown.

${ }^{* * *} p<.01,{ }^{* *} p<.05,{ }^{*} p<.1$.

\section{Results}

Table 1 presents two sets of results. Model (1) uses an unbalanced panel of all countries for which at least five time-series observations were possible. This group

Following the arguments of Easterly and Levine 1997, models were also estimated that controlled for ethnic fractionalization (as measured in the Atlas Narodov Mira 1964 and presented in Taylor and Hudson 1972). This variable was unavailable for several countries and the data are of questionable quality. In any case, the inclusion of this variable for a smaller sample did not affect any of the results. 
includes forty-four countries with 503 total observations with an average of twelve years per country. Model (2) uses the best possible complete balanced panels, which includes twenty-five countries from 1980 to 1993.

The results are consistent with the "common pool" hypothesis. Other things equal, the predicted effect of a long-term 10 percent increase in grants as a share of total government revenue (for example, going from 10 percent - the mean value for the entire data set-to 11 percent) is somewhere between a 0.03 and 0.05 percent increase in the growth of the public sector. This result withstands a number of robustness checks and alternative estimation techniques. In fact, a relaxation of the five-year time-series cutoff allows for the inclusion of 600 observations from fifty-nine countries, which also yields similar results. Similar or even more pronounced results were found no matter what criteria were used for the inclusion of cases, and the result is not affected by dropping countries or even entire regions. ${ }^{48}$ Finally, because of the potential bias associated with including the lagged level of the dependent variable in a fixed effects model, similar models were estimated using the Praise-Winsten transformation, as well as the generalized method of moments (GMM) estimator derived by Arellano and Bond, again yielding very similar coefficients and standard errors.

The negative coefficient on lagged "own-source" revenue (as a share of total revenue) is intriguing but difficult to interpret. It would appear that other things equal, a relative shift in resources away from the central government-if funded by sources other than budgetary grants-actually curbs the growth of government. This variable is not an acceptable proxy for the type of decentralization implied by the Leviathan literature, but the result invites the more refined analysis pursued below. ${ }^{49}$

\section{A Closer Look at Grants}

Fiscal decentralization, when funded by intergovernmental transfers from the central government, is associated with increasing overall public expenditures. Thus far it is unclear, however, whether this is driven by expenditures at the sub-

48. Separate effects were also estimated for federal and unitary countries, and the coefficients are quite similar for both.

49. The coefficients for most of the control variables behave as expected. The negative short-term coefficient for GDP per capita would seem to indicate counter-cyclical expenditure policy or smoothing. Because GDP is the denominator in the dependent variable, this suggests that expenditure growth lags behind the growth of the private sector during short-term booms and exceeds the growth of the private sector during short-term downturns. Larger countries demonstrate faster-growing government spending. The dependency ratio is a good predictor of government spending in the smaller sample but not the larger sample, which includes more non-OECD countries. Open capital accounts are associated with faster government growth. The conditional coefficients involving veto players tell a surprising story. When lagged deficits are large, increasing the number of veto players has a slight negative effect on government growth, but the effect becomes positive for a lagged surplus. Finally, election years are associated with higher expenditures in the smaller sample. 
national level, the central level, or both. This section examines central and subnational expenditures separately. Rather than examining grants and "own-source" local revenues as portions of total revenues as before, here they are entered as shares of GDP to facilitate direct comparisons of their stimulative effects on expenditures at each level:

$$
\begin{aligned}
\triangle \text { GOVERNMENT SIZE }_{\mathrm{it}}= & \beta_{0}+\beta_{1} \Delta \text { GOVERNMENT SIZE } E_{\mathrm{it}-1} \\
& +\beta_{2} \Delta \text { GRANTS } / \text { GDP } P_{\mathrm{it}} \\
& +\beta_{3} \Delta L O G \text { GDP PER CAPITA } \mathrm{it}_{\mathrm{it}} \\
& +\Sigma P A N E L \text { DUMMIES }+\varepsilon
\end{aligned}
$$

where government size is either SUBNATIONAL EXPENDITURE/GDP (model 3) or (CENTRAL GOVERNMENT EXPENDITURES-GRANTS)/GDP (model 4) in country $i$ at year $t$. Borrowing from the empirical literature on the flypaper effect, the primary goal is to estimate the effect of changes in grants on changes in expenditures to obtain the marginal effect of a one-unit increase in grants on expenditures. ${ }^{50}$ The basic question of this section is whether increased grants substitute or complement other forms of subnational revenue or central government expenditure.

First of all, when a subnational government receives an increase in grants, what portion of the increase goes to increased expenditures versus decreased local taxation? This is the key empirical question of the flypaper literature. For the regression in which SUBNATIONAL EXPENDITURE/GDP is the dependent variable (model 3), it is not necessary in three-tiered systems to combine the state and municipal sectors as above. Rather, because subnational rather than total expenditures are being estimated, the state and municipal sectors in such systems can be entered as separate panels, providing a greater number of observations.

Model (3) in Table 2 affords a simple estimation of the flypaper effect using each state and local sector used in Model 1 above. ${ }^{51}$ The coefficient for $\Delta$ GRANTs/ GDP is close to unity. A one-unit increase in grants is associated with a 0.97 unit increase in expenditures by subnational governments. In the literature on the flypaper effect, this is at the upper end of the spectrum of findings for block grants. ${ }^{52}$ Aggregate data for entire state or municipal sectors are quite blunt, and the grant programs around the world vary widely from specific-purpose matching grants to

50. Though similar results with a slightly better fit can be obtained using logarithmic transformations of the fiscal variables, here the interpretation of the coefficients is more intuitive using the raw data.

51. The overall fit and results of models (4) and (5) are unaffected by the inclusion of the control variables included in models (1) to (3).

52. Endogeneity likely biases the results of flypaper models using OLS. Above all, expenditures will affect grants in countries using matching grants. An alternative is the GMM estimator derived by Arellano and Bond 1991. This approach uses first differences and instrumental variable estimation, where the instruments are the lagged explanatory variables and lagged dependent variable (in differences). This approach yields a coefficient of 0.93 . Using a range of different samples and estimation techniques, 0.93 was the lowest coefficient obtained, and the highest was slightly over 1 . 
TABLE 2. Estimates of changes in the size of subnational and central government, disaggregated analysis

\begin{tabular}{|c|c|c|c|c|}
\hline Dependent variable & \multicolumn{2}{|c|}{$\begin{array}{l}\triangle \text { SUBNATIONAL } \\
\text { EXPENDITURE/GDP }\end{array}$} & \multicolumn{2}{|c|}{$\begin{array}{l}\triangle \text { NON-GRANT CENTRAL } \\
\text { GOVT. EXPENDITURE/GDP }\end{array}$} \\
\hline \multicolumn{5}{|l|}{ Independent variables } \\
\hline$\Delta$ GRANTS/GDP & 0.975 & $(0.074)^{* * *}$ & 0.537 & $(0.314)^{*}$ \\
\hline$\triangle$ LOG GDP PER CAPITA & 0.002 & $(0.002)$ & -0.063 & $(0.044)$ \\
\hline$\triangle$ DEPENDENT VARIABLE $t-1$ & -0.053 & $(0.073)$ & -0.122 & $(0.154)$ \\
\hline Constant & 0.0003 & $(0.003)$ & 0.017 & $(0.024)$ \\
\hline Observations & \multicolumn{2}{|c|}{597} & \multicolumn{2}{|c|}{507} \\
\hline Number of panels & \multirow{2}{*}{\multicolumn{2}{|c|}{53}} & \multicolumn{2}{|c|}{44} \\
\hline & & 0.41 & \multicolumn{2}{|c|}{0.07} \\
\hline
\end{tabular}

Note: Panel-corrected standard errors in parentheses. Estimates for fixed unit effects not reported.

${ }^{* * *} p<.01,{ }^{* *} p<.05,{ }^{*} p<.1$.

open-ended block grants-but these results suggest that as an empirical phenomenon the flypaper effect is quite universal. Subnational governments appear to spend virtually all of the grants they receive from higher-level governments.

The next question is whether, when central governments increase their expenditures on grants to subnational governments, there is a corresponding decrease in direct (nongrant) central government expenditures. Model (4) uses the same independent variables as model (2) but examines the central government's expenditures (net of grants) instead. ${ }^{53}$ If increased grants merely substitute for forms of expenditure that were formerly provided directly by the center, the coefficient would be negative. The results presented in Table 2 show that the coefficient is actually positive (though only significant at the 10 percent level) - increasing transfers are associated with increases in other forms of expenditure as well.

In short, this section has added precision to the relationship between grants and the growth of government demonstrated in the previous section. Increased grants to subnational governments appear to supplement rather than replace existing central government expenditure programs, while virtually the entire increase is spent by the recipient government.

\section{A Closer Look at Tax Autonomy}

The negative effect of "own-source" revenue decentralization on the growth of government discussed above is interesting, but it must not be construed as support

53. Similar to models (1) to (2), the subnational variables are once again state-local aggregations in three-tiered systems. 
for the Leviathan hypothesis. While the GFS measure is a good start (and the only available cross-national time-series data), it drastically overestimates local revenue autonomy in cases where "own-source" subnational revenue is merely the output of a revenue-sharing scheme or where the tax rate and/or base are set by the central government. Fortunately, a recent report published by the OECD has undertaken the first systematic cross-national examination of subnational tax autonomy ${ }^{54}$ Although the OECD report only covers a small number of countries and does not examine changes over time, it contains valuable new information from which it is possible to calculate the share of total tax revenue for which subnational governments not only collect revenue, but also set the base and rate themselves. ${ }^{55}$ The OECD study reveals that some local government sectors, such as the Danish municipalities and counties-although they raise a good deal of revenue-do not determine the bases and rates. Thus the value of this variable for Denmark is zero. At the other end of the spectrum, 30 percent of tax revenue in Canada is legislated and collected by the provinces and local governments. (See the descriptive statistics in the Appendix). Tax competition, and hence the Leviathan hypothesis, is much more plausible in countries such as Canada than in countries such as Denmark.

Because the OECD researchers collected their data in the early 1990s, it is useful to plot the tax autonomy index against the average size of government from 1985 to 1995 . One of the key lessons of the OECD study is immediately clear in Figure 3: full tax decentralization is more unusual than commonly thought. The three developed, highly decentralized federations-Canada, Switzerland, and the United States-are in a class by themselves and their public sectors are among the smallest in the sample. By contrast, although welfare expenditures and even revenue collection are quite decentralized in the Scandinavian countries, either the tax rates, the determination of the base, or both are tightly regulated by the center. ${ }^{56}$

Perhaps the ideal empirical test of the Leviathan hypothesis would be a "natural experiment" in which some countries radically decentralize tax authority over time. In fact, Spain and Belgium may provide such an opportunity in the years ahead. But as a second-best approach, though the degrees of freedom are low, the tax autonomy index is a poor proxy for actual tax competition, and there are limits to what can be learned from cross-section averages, it is useful to estimate a simple regression on cross-section averages to examine the long-term effect of fiscal decentralization that features autonomous subnational taxation. The tax autonomy variable can be used in an interactive specification to examine the longterm effects of decentralization on the size of government at various levels of tax autonomy:

54. OECD 1999.

55. The OECD study does not include the United States and Canada. For these cases, I applied the OECD methodology to data collected from country sources.

56. Note that the index looks very different if the focus is solely on autonomy over rates. For instance, Swedish local governments do have wide-ranging autonomy over rates. 


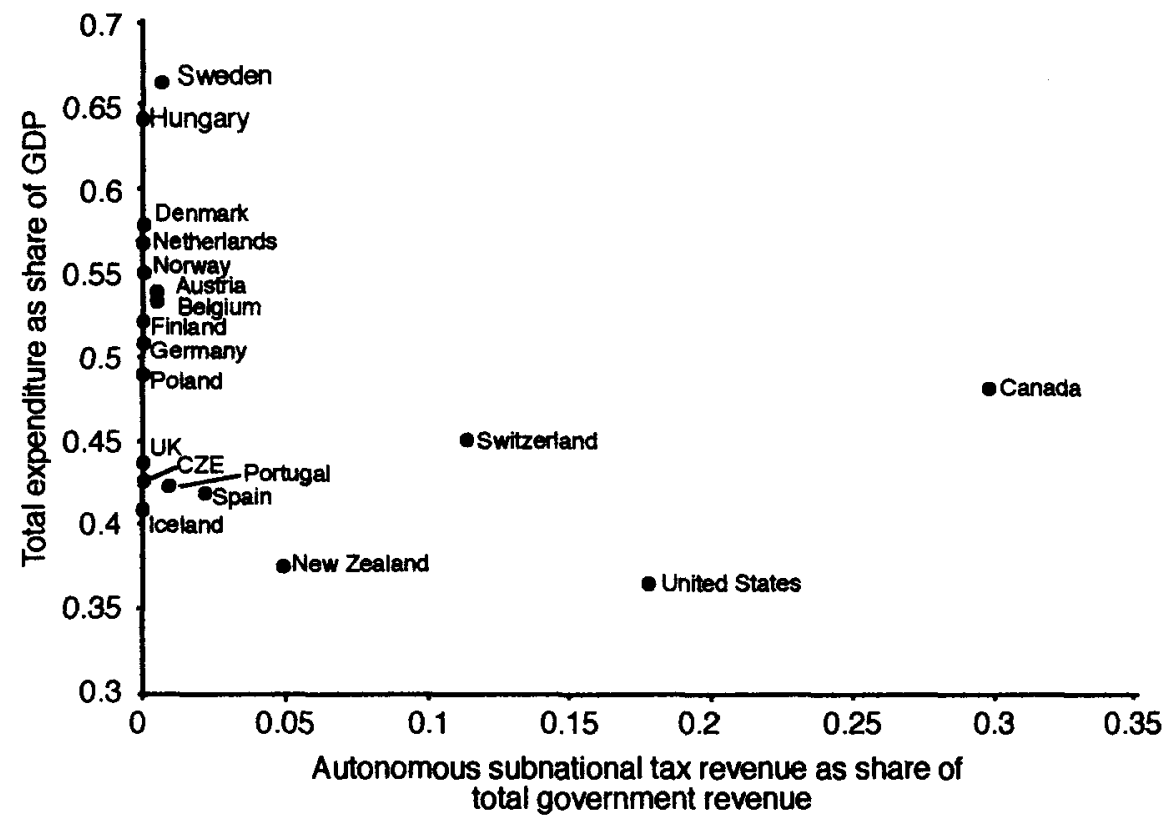

FIGURE 3. Subnational tax autonomy and the size of government

$$
\begin{aligned}
& \text { LOG AVE. GOVERNMENT SIZE } E_{\mathrm{i}} \\
& =\beta_{0}+\beta_{1} \text { LOG AVE. AUTONOMOUS TAXES/SUBNAT.REVENUE } \mathrm{i} \\
& +\beta_{2} \text { LOG AVE. SUBNAT. REVENUE/TOTAL REVENUE } \\
& +\beta_{3} \text { LOG AVE. AUTONOMOUS TAXES/TOTAL REVENUE } \mathrm{i}_{\mathrm{i}} \\
& +\Sigma C O N T R O L S+\varepsilon
\end{aligned}
$$

The second term is the long-term (1985-95) average level of total government revenues accruing to subnational governments-the decentralization variable used in most previous studies using cross-country averages. The first term measures autonomous subnational taxation as a share of subnational revenue, and the third term (displayed in its raw form in Figure 3) is the multiplicative interaction of the first two. This setup allows for the calculation of conditional fiscal decentralization effects at different levels of subnational tax autonomy. The regression is presented in Table 3, and the conditional coefficients are plotted in Figure 4. 
TABLE 3. Estimates of long-term average size of government (1985-95), OECD sample

LOG TOTAL GOVERNMENT SPENDING/GDP

Independent variables

LOG AUTONOMOUS SUBNATIONAL TAX REVENUE/SUBNATIONAL REVENUE

LOG SUBNATIONAL REVENUE/TOTAL REVENUE

LOG AUTONOMOUS SUBNATIONAL TAX REVENUE/TOTAL REVENUE

0.48

0.57

$-2.93$

Control variables

LOG GDP PER CAPITA

LOG POPULATION

AREA (log square $\mathrm{km}$ )

DEPENDENCY RATIO

TRADE/GDP

WESTERN EUROPE DUMMY

EASTERN EUROPE DUMMY

Constant

Number of countries

$R^{2}$
$-0.22$

0.01

0.09

1.10

1.16

$-0.36$

$-0.18$

$-0.10$

18

0.93
$(0.46)$

$(0.11) * * *$

$(0.96)^{* * *}$

(0.17)

$(0.02)$

$(0.03)^{* * *}$

$(0.85)$

$(0.18)^{* * *}$

$(0.11)^{* *}$

$(0.15)$

Note: Model 5 is an ordinary least squares (OLS) "between effects" model. Standard errors in parentheses. ${ }^{* * *} p<.01, * * p<.05,{ }^{*} p<.1$.

In spite of the small number of observations, the variables of interest are highly significant. The $R^{2}$ is 0.93 , while for the same model without the fiscal federalism variables it is $0.61 .^{57}$ In Figure 4, the horizontal axis represents the share of subnational revenue that is raised through autonomous local taxation, while the vertical axis represents conditional coefficients for the estimated effect of revenue decentralization on the long-term average size of government. The bold line is the conditional effect and the gray lines represent the 95 percent confidence interval. At the far left, decentralization is driven exclusively by revenue sources that the subnational governments do not directly control (grants, shared revenue, or centrally regulated taxes). This type of decentralization has a significant positive relationship with the average size of government. Figure 4 indicates that the majority of the OECD cases fall in this range. Moving to the right, decentralization has a smaller positive estimated effect on the size of government as subnational governments gain tax autonomy, and the coefficient is reversed when we reach the range of Switzerland, the United States, New Zealand, and Canada. Obviously the neg-

57. Only the control variables that approached statistical significance are included, along with region dummies. 


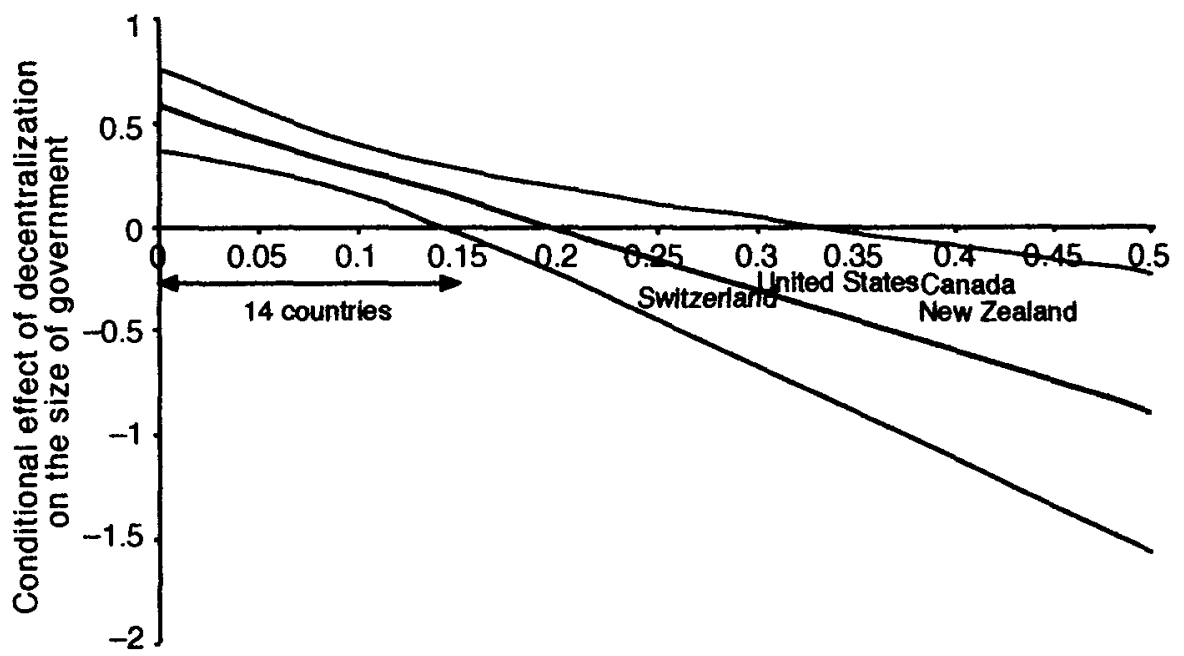

\section{Log autonomous taxation/subnational revenue}

FIGURE 4. The conditional effect of decentralization on the size of government (model 5, cross-country averages)

ative conditional coefficients should be interpreted with caution, because they are based on such a small number of cases (as indicated by the widening confidence bands), but the results are similar if influential cases or even pairs of cases are dropped.

As a third-best approach, though the variable taken from the OECD study does not exhibit time-series variation, it is reasonable to assume that tax autonomy is relatively stable over time ${ }^{58}$ and estimate an ECM model similar to models (1) and (2) using the smaller OECD data set, interacting the tax autonomy variable with the "own-source" decentralization variable to differentiate between the effects of "own-source" decentralization in countries with and without substantial tax autonomy.

Model (6), presented in Table 4, takes a simple approach. Given the skew in the tax autonomy data (see Figure 3), it makes sense to divide the countries into two discreet groups. Canada, the United States, Switzerland, and New Zealand can be classified as having high subnational tax autonomy and the others as low. Model (6) simply replicates model (1) but interacts the "own-source" decentralization variables with dummies for "high" and "low" tax autonomy. Controlling for grants (which demonstrate a similar positive effect on total expenditures as in larger sam-

58. The coverage does not include recent reforms in Spain and Belgium. 
TABLE 4. Estimates of changes in total government expenditure as share of GDP, OECD sample

Dependent variable

$\triangle$ LOG TOTAL EXPENDITURE/GDP

\section{Independent variables}

$\Delta$ LOG GRANTS/TOTAL REVENUE

LOG GRANTS/TOTAL REVENUE t-1 $_{1}$

$\triangle$ LOG "OWN-SOURCE" SUBNATIONAL REVENUE/ TOTAL REVENUE $\times$ HIGH TAX AUTONOMY LOG "OWN-SOURCE" SUBNATIONAL REVENUE/ TOTAL REVENUE $-1 \times$ HIGH TAX AUTONOMY

$\triangle$ LOG "OWN-SOURCE" SUBNATIONAL REVENUE/ TOTAL REVENUE $\times$ LOW TAX AUTONOMY LOG "OWN-SOURCE" SUBNATIONAL REVENUE/ TOTAL REVENUE $1-1 \times$ LOW TAX AUTONOMY

$\triangle$ LOG "OWN-SOURCE" SUBNATIONAL REVENUE/ TOTAL REVENUE

LOG "OWN-SOURCE" SUBNATIONAL REVENUE/ TOTAL REVENUE -1

LOG AUTONOMOUS SUBNATIONAL TAX REVENUE/ "OWN-SOURCE" SUBNATIONAL REVENUE LOG AUTONOMOUS SUBNATIONAL TAX REVENUE/ TOTAL REVENUE

$\begin{array}{cl}0.024 & (0.014)^{*} \\ 0.027 & (0.008)^{* * *} \\ -0.270 & (0.196) \\ -0.188 & (0.078)^{* * *} \\ 0.038 & (0.015)^{* * *} \\ 0.015 & (0.017)\end{array}$

\section{Control variables}

$\triangle$ LOG GDP PER CAPITA

LOG GDP PER CAPITA $\mathrm{t}_{\mathrm{t}-1}$

$\triangle$ LOG POPULATION

LOG POPULATION -1

AREA (log square $\mathrm{km}$ )

$\triangle$ DEPENDENCY RATIO

DEPENDENCY RATIO I-1 $^{-1}$

$\triangle$ TRADE/GDP

TRADE/GDP t-1

OPENNESS

CENTRAL GOVT. SURPLUS $\mathrm{t}_{-1}$

VETO PLAYERS

VETO PLAYERS $\times$ CENT. GOVT. SURPLUS $S_{1-1}$

EXECUTIVE ELECTION YEAR

SYSTEM (pres/parl)

PARTISANSHIP OF EXECUTIVE

LOG TOTAL EXPENDITURE/GDP

\begin{tabular}{|c|c|c|c|}
\hline-0.958 & $(0.103)^{* * *}$ & -1.000 & $(0.096)^{* * *}$ \\
\hline-0.040 & $(0.057)$ & -0.022 & $(0.037)$ \\
\hline-1.038 & $(1.664)$ & -0.214 & $(1.371)$ \\
\hline \multirow[t]{2}{*}{0.126} & $(0.155)$ & 0.002 & $(0.006)$ \\
\hline & & 0.007 & $(0.005)$ \\
\hline-0.662 & $(1.020)$ & -0.363 & $(0.894)$ \\
\hline-0.072 & $(0.225)$ & 0.041 & $(0.102)$ \\
\hline 0.083 & $(0.071)$ & 0.122 & $(0.066) *$ \\
\hline-0.002 & $(0.062)$ & 0.064 & $(0.037)^{*}$ \\
\hline 0.015 & $(0.009)^{*}$ & -0.002 & $(0.009)$ \\
\hline 0.274 & $(0.163) *$ & 0.242 & $(0.177)$ \\
\hline-0.003 & $(0.004)$ & -0.001 & $(0.003)$ \\
\hline-0.094 & $(0.047)^{* *}$ & -0.042 & $(0.038)$ \\
\hline-0.010 & $(0.011)$ & -0.014 & $(0.010)$ \\
\hline 0.321 & $(0.411)$ & 0.027 & $(0.017)$ \\
\hline 0.003 & $(0.003)$ & 0.003 & $(0.003)$ \\
\hline-0.239 & $(0.062)^{* * *}$ & -0.091 & $(0.026)^{* * *}$ \\
\hline-1.852 & $(2.372)$ & 0.058 & $(0.357)$ \\
\hline & & & \\
\hline & 8 & & 8 \\
\hline & & & \\
\hline
\end{tabular}

Constant

Observations

Number of countries

$R^{2}$

$\begin{array}{ll}0.043 & (0.017)^{* * *} \\ 0.026 & (0.013)^{* *} \\ 0.126 & (0.087) \\ -0.690 & (0.293)^{* *}\end{array}$

Note: Panel-corrected standard errors in parentheses. Model 6 includes fixed country effects (not reported). Model 7 includes a panel of region dummies (not reported).

${ }^{* * *} p<.01,{ }^{* *} p<.05,{ }^{*} p<.1$. 


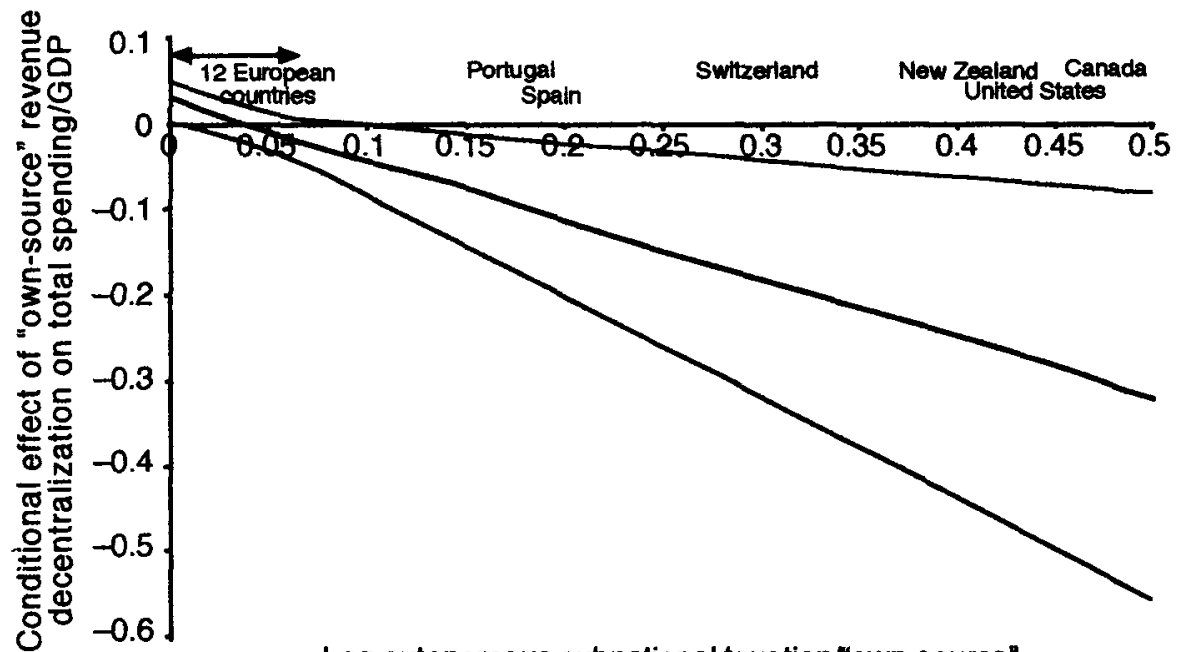

\section{Log autonomous subnational taxation/"own-source" subnational revenue}

FIGURE 5. The conditional effect of "own-source" decentralization on the size of government (model 7, time series cross-section)

ples above), long-term "own-source" fiscal decentralization has a large negative effect on the growth of government in Canada, Switzerland, New Zealand, and the United States, and a positive (though not quite statistically significant) effect elsewhere. ${ }^{59}$

Another approach is taken in model (7), which uses the full range of variation in the (logged) tax autonomy index by interacting AUTONOMOUS SUBNATIONAL TAXATION/SUBNATIONAL "OWN-SOURCE" REVENUE with the lag of SUBNATIONAL "OWN-SOURCE REVENUE"/TOTAL REVENUE. This allows for the calculation of conditional coefficients that capture the estimated long-term effect of "own-source" decentralization at different levels of tax autonomy. ${ }^{60}$ Figure 5 plots the conditional coefficients over the sample range, showing that the effect of decentralization is neutral or slightly positive for the majority of OECD countries where most

59. This result has been subjected to the same alternative specifications, sensitivity analysis, and sample restrictions as described above. The result is similar with or without the United States or Canada, but the significance falls below the 10 percent level if the most influential case-Switzerland-is dropped.

60. A disadvantage of this approach is that it is not possible to include fixed country effects because of their correlation with the tax autonomy variable. Model (7) includes a panel of region dummies instead. The results are not substantially altered by the inclusion of dummy variables for influential cases or simply dropping influential cases from the analysis. 
subnational revenue generation is regulated by the center. Moving to the rightwhere state and local governments obtain larger portions of their "own-source" revenues from taxes over which they directly control the base and rate-tax decentralization is associated with smaller government.

Although falling short of incontrovertible proof, the results presented in this section should at least revive the Leviathan debate. But as with the positive effect of intergovernmental grants, the results do not suggest how to discriminate among the possible causal mechanisms. Tax competition might suppress government spending by limiting the taxation of mobile assets. Or if one adopts the perspective that democratic governments naturally tend toward excess, greater reliance on local taxation might reduce fiscal illusion, tighten the tax-benefit link, and strengthen incentives for oversight, perhaps through benchmark competition. Alternatively decentralization might simply resolve the common pool problem associated with centralized budgeting, though in this case one might expect to find that any tax decentralization would reduce the size of government regardless of how the base and rate are determined, which is apparently not the case.

The most important weakness of the analysis conducted in this section is its reliance on three cases - the United States, Switzerland, and Canada - that might be "special" for some reason other than tax decentralization, or that may have something in common that drives both tax decentralization and smaller government. ${ }^{61}$ If so, one must go beyond the simple common thread of "federalism," traditionally defined as special rights and protections for provinces in the constitution and representation in an upper legislative chamber. For example, Germany and Austria have these features without tax decentralization or small public sectors. The introduction of a federalism dummy variable does not change any of the results in this article, nor does it approach statistical significance. ${ }^{62}$ A more likely omitted variable has something to do with mutual suspicions owing to past civil wars or racial and linguistic differences that may have had a role in suppressing both the centralization of taxation and the growth of government. Perhaps the next step in this literature-both as a solution to the endogeneity problem and a way of choosing among the various causal mechanisms described above-is to go beyond the recent time slice and conduct a comparative historical analysis of (de)centralized taxation and the growth of government.

61. Of course, the results are also only as trustworthy as the quality of the tax autonomy variable, which is still a very rough approximation. For example, subnational governments in some countries, such as Sweden, have considerable autonomy over the tax rate but not the base, which may nevertheless facilitate competition. When autonomy over the rate only is used to construct the variable, the results are not statistically significant.

62. Another possible omitted variable concerns the size and structure of jurisdictions. One possibility raised in the Leviathan literature is that tax competition is more intense when jurisdictions are small and plentiful. In practice, however, smaller jurisdictions are less likely to have tax autonomy. Variables such as the number of jurisdictions, kilometers per jurisdiction, and persons per jurisdiction have been introduced the regressions above without producing significant results. 


\section{Conclusions}

Those who are alarmed that the global trend toward fiscal decentralization entails dangerous tax competition have little to fear, and those who envision smaller, more efficient government have little to celebrate. Even in the most developed countries, subnational expenditures are most often funded by revenue-sharing schemes, taxes that are controlled by the central government, or outright intergovernmental transfers. In general, the trend toward fiscal decentralization is not moving countries closer to Hayek's "economic conditions of interstate federalism" or Weingast's "market-preserving federalism." These envision powerful, self-financing local governments and a credibly limited central government. If anything, decentralizing countries are moving closer to the overlapping, intertwined multitiered state described by Fritz Scharpf ${ }^{63}$ in which the finances of the central and local governments are increasingly difficult to disentangle.

However, neither the rarity of subnational tax autonomy in practice nor skepticism about revenue-hungry monsters implies that the link between tax decentralization and smaller government should be rejected. Rent-seeking assumptions are not necessary to see that interjurisdictional tax competition limits the ability of immobile asset owners to tax more mobile asset owners. Previous cross-national studies may have been looking for Leviathan in the wrong places using the wrong techniques. Using a limited OECD sample, this article presents evidence that decentralization-when funded primarily by autonomous local taxation-is associated with a smaller public sector. This helps explain why support has been found for the Leviathan hypothesis in time-series case studies of the United States, Canada, and Switzerland but not in larger cross-national studies. When funded by revenue-sharing, grants, or centrally regulated subnational taxation, fiscal decentralization is, if anything, associated with larger government in the OECD sample examined in this article. Using a much larger global sample, this article has also shown that decentralization funded by direct intergovernmental transfers is associated with a larger public sector-a heretofore untold part of the story of government growth around the world during the past twenty years ${ }^{64}$ When central governments increase transfers to subnational governments, they do not reduce their own direct expenditures, and subnational governments spend virtually every dollar of increased transfers.

One should be careful about divining normative or policy implications from these results. Both of the main results are consistent with "responsive" and "excessive" notions of government expenditure, and both are consistent with fiscal decentralization either improving or diminishing the welfare of the representative voter. Perhaps tax decentralization unjustly favors owners of mobile capital and leads to the underprovision of public goods or redistribution, but it might also

63. Scharpf 1976.

64. For individual case studies see Borge and Rattsø 2002; and Winer 1980. 
eliminate waste, improve accountability, and help government commit to a policy of nonconfiscatory capital taxation. Moreover, decentralization that is funded by intergovernmental grants or revenue-sharing might reflect an efficient response to new demands for public goods that local governments are well positioned to provide but poorly equipped to fund. Demands for decentralization-especially when part of the process of democratization-might be accompanied by demands for increased redistribution and risk sharing that can only be funded by the central government. But on the other hand, there are good reasons for concern that increased reliance on intergovernmental transfers generates agency and common pool problems, especially when subnational governments have access to credit markets and the central government is politically weak. ${ }^{65}$

Given the problems associated with fiscal indiscipline and debt in countries that have decentralized by expanding intergovernmental transfers, it is tempting to conclude that the correlation between grants and larger government is indicative of the inefficiencies highlighted in theories of "excessive" government. However, such a conclusion would require theory and evidence about why countries choose decentralization in the first place, and how they choose their mixtures of grants, revenue-sharing, and local taxes. An increase in grants or revenue-sharing might represent an attempt by the center to shed uncomfortable responsibilities or a strategy in the game of distributive politics, but it might also represent a response to citizens' demands for better local services.

In short, this article has presented some interesting correlations, but the empirical setup does not allow for strong conclusions about causality. This is often the case with cross-country regressions, which are most useful when they shape-and in turn are shaped by-careful case studies. Explicitly comparative county studies are the best way to clarify the causal mechanisms linking intergovernmental fiscal structure and governmental spending. To sort out the causal mechanisms behind the results in this article and get a clearer picture of their normative and policy implications, it is necessary to make cross-national and time-series variations in the vertical fiscal structure of government endogenous. A difficult, but rewarding, further step for cross-national research is to explore political and economic history to find instruments for the relative centralization of taxation and expenditures across countries and over time. ${ }^{66}$

Fiscal decentralization likely has far-reaching implications not only for government's size, but also for its quality and accountability. The devil is in the details, and many questions remain unanswered. But in the final analysis, empirical investigation cannot answer a question that is at its heart ideological. Leviathan will always be a dangerous beast for some and a figment of the imagination for others.

65. Rodden 2002, 2003.

66. For first attempts that ignore the distinction between grants and subnational taxation and focus on recent decades, see Panizza 1999; and Garrett and Rodden 2003. 


\section{Appendix: Descriptive Statistics and Country Coverage}

\begin{tabular}{|c|c|c|c|c|}
\hline & Mean & Std. Dev. & Min. & $\operatorname{Max}$. \\
\hline \multicolumn{5}{|l|}{ Forty-fou-country sample (models $1,3,4$ ) } \\
\hline TOTAL EXPENDITURE/GDP & 0.41 & 0.15 & 0.07 & 1.02 \\
\hline SUBNATIONAL EXPENDITURE/GDP & 0.12 & 0.09 & 0.002 & 0.36 \\
\hline NON-GRANT CENTRAL GOVT. EXPENDITURE/GDP & 0.30 & 0.12 & 0.07 & 0.95 \\
\hline INTERGOVERNMENTAL GRANTS/GDP & 0.04 & 0.04 & 0.0001 & 0.18 \\
\hline GRANTS/TOTAL REVENUE & 0.11 & 0.09 & 0.0004 & 0.42 \\
\hline \multicolumn{5}{|l|}{ "OWN-SOURCE" SUBNATIONAL } \\
\hline REVENUE/TOTAL REVENUE & 0.17 & 0.13 & 0.02 & 0.55 \\
\hline GDP PER CAPITA & 8651 & 5178 & 837 & 18975 \\
\hline POPULATION (millions) & 54.36 & 132.43 & 0.25 & 913.60 \\
\hline AREA $(\log$ square $\mathrm{km})$ & 173174 & 183339 & 2639 & 741570 \\
\hline DEPENDENCY RATIO & 0.61 & 0.14 & 0.44 & 0.98 \\
\hline TRADE/GDP & 0.67 & 0.39 & 0.09 & 2.09 \\
\hline OPENNESS & 0.41 & 0.49 & 0 & 1 \\
\hline DEMOCRACY & 6.37 & 5.77 & -10 & 10 \\
\hline VETO PLAYERS & 2.95 & 1.71 & 1 & 13 \\
\hline CENTRAL GOVT. SURPLUS/GDP & -0.04 & 0.05 & -0.30 & 0.05 \\
\hline SYSTEM (pres/parl) & 1.45 & 0.85 & 0 & 2 \\
\hline EXECUTIVE ELECTION YEAR & 0.06 & 0.23 & 0 & 1 \\
\hline PARTISANSHIP OF EXECUTIVE & 0.10 & 0.85 & -1 & 1 \\
\hline \multicolumn{5}{|l|}{ OECD sample (models $5,6,7$ ) } \\
\hline \multicolumn{5}{|l|}{ AUTONOMOUS SUBNATIONAL TAX REVENUE/ } \\
\hline SUBNATIONAL REVENUE/TOTAI. REVENUE & 0.37 & 0.16 & 0.09 & 0.73 \\
\hline AUTONOMOUS SUBNATIONAL TAX REVENUE/ & & & & \\
\hline TOTAI. REVENUE & 0.04 & 0.08 & 0 & 0.30 \\
\hline
\end{tabular}

Note: The forty-four-country sample used in models 1, 3, and 4 includes all of the following countries, while the smaller "balanced panel" sample used in model 2 includes only the countries in italics: Australia, Austria, Belgium, Bolivia, Brazil, Bulgaria, Canada, Chile, Colombia, Costa Rica, Denmark, Fiji, Finland, France, Germany, Greece, Iceland, India, Indonesia. Iran, Ireland. Israel, Italy, Kenya. Luxembourg, Malaysia, Mexico, Netherlands, New Zealand, Nicaragua, Nomiay, Panama, Paraguay, Peru, Philippines. Romania, South Africa, Spain, Sweden, Switzerland, Thailand, UK, United States, and Zimbabwe. The countries included in the smaller OECD sample used in models 5 , 6 , and 7 are displayed in Figure 3.

\section{References}

Alesina, Alberto, and Allan Drazen. 1998. Why Are Stabilizations Delayed? In The Political Economy of Reform, edited by Federico Sturzenegger and Mariano Tommasi, 77-103. Cambridge, Mass.: MIT Press.

Arellano, Manuel, and Stephen Bond. 1991. Some Tests of Specification for Panel Data: Monte Carlo Evidence and an Application in Employment Equations. Review of Economic Studies 58 (2):277-97.

Bardhan, Pranab, and Dilip Mookherjee. 2000. Capture and Governance at Local and National Levels. American Economic Review 90 (2):135-39.

Berry, William, and David Lowery. 1987. Explaining the Size of the Public Sector: Responsive and Excessive Government Interpretations. Joumal of Politics 49 (2):401-40. 
Besley, Timothy, and Ann Case. 1995. Incumbent Behavior: Vote-Seeking, Tax-Setting, and Yardstick Competition. American Economic Review 85 (1):25-45.

Bolton, Patrick, and Gerard Roland. 1997. The Breakup of Nations: A Political Economy Analysis. Quarterly Journal of Economics 112 (4): 1057-90.

Borge, Lars-Erik, and Jørn Rattsø. 2002. Spending Growth with Vertical Fiscal Imbalance: Decentralized Government Spending in Norway: 1880-1990. Economics and Politics 14 (3):351-73.

Bradford, David, and Wallace Oates. 1971. Towards a Predictive Theory of Intergovernmental Grants. American Economic Review 61 (2):440-48.

Brennnan, Geoffrey, and James Buchanan. 1980. The Power to Tax: Analytical Foundations of a Fiscal Constitution. Cambridge: Cambridge University Press.

Buchanan, James. 1977. Why Does Government Grow? In Budgets and Bureaucrats, edited by Thomas Borcherding, 3-18. Durham, N.C.: Duke University Press.

1995. Federalism as an Ideal Political Order and an Objective for Constitutional Reform. Publius 25 (2): 19-27.

Buchanan, James, and Richard Musgrave. 1999. Public Finance and Public Choice: Two Contrasting Visions of the State. Cambridge, Mass.: MIT Press.

Buchanan, James, and Richard Wagner. 1977. Democracy in Deficit: The Political Legacy of Lord Keynes. New York: Academic Press.

Cameron, David R. 1978. The Expansion of the Public Economy: A Comparative Analysis. American Political Science Review 72 (4):1243-61.

Careaga, Maite, and Barry R. Weingast. 2000. The Fiscal Pact with the Devil: A Positive Approach to Fiscal Federalism, Revenue Sharing, and Good Governance. Paper presented at the Conference on Political Institutions and Economic Growth in Latin America, April, Stanford, Calif.

Easterly, William, and Ross Levine. 1997. Africa's Growth Tragedy: Policies and Ethnic Divisions. Quarterly Journal of Economics 112 (4):1203-50.

Eichengreen, Barry, and Jürgen von Hagen. 1996. Fiscal Restrictions and Monetary Union: Rationales, Repercussions, Reforms. Empirica 23 (1):3-23.

Feld, Lars, Gebhard Kirchgässner, and Christoph Schaltegger. Decentralized Taxation and the Size of Government: Evidence from Swiss State and Local Governments. Unpublished manuscript, University of St. Gallen, Switzerland.

Franzese, Robert. 2001. The Positive Political Economy of Public Debt: An Empirical Examination of the Postwar OECD Experience. Unpublished paper, University of Michigan, Ann Arbor.

Garrett, Geoffrey. 2001. Globalization and Government Spending Around the World. Studies in Comparative International Development 35 (4):3-29.

Garrett, Geoffrey, and Jonathan Rodden. 2003. Globalization and Fiscal Decentralization? In Governance in a Global Economy: Political Authority in Transition, edited by Miles Kahler and David Lake. Princeton, N.J.: Princeton University Press (forthcoming).

Grossman, Philip J. 1989. Fiscal Decentralization and Government Size: An Extension. Public Choice $62(1): 63-69$.

Grossman, Philip J., and Edwin G. West. 1994. Federalism and the Growth of Government Revisited. Public Choice 79 (1-2):19-32.

Hayek, Friedrich von. 1939. The Economic Conditions of Interstate Federalism. New Commonwealth Quarterly V (2):13I-49. Reprinted in Friedrich von Hayek. 1957. Individualism and Economic Order. Chicago: University of Chicago Press.

Hines, James R., Jr., and Richard H. Thaler. 1995. Anomalies: The Flypaper Effect. Journal of Economic Perspectives 9 (4):217-26.

Inman, Robert, and Daniel Rubinfeld. 1997. The Political Economy of Federalism. In Perspectives on Public Choice: A Handbook, edited by Dennis Mueller, 73-105. Cambridge: Cambridge University Press.

Inter-American Development Bank. 1997. Fiscal Decision Making in Decentralized Democracies. In Latin America After a Decade of Reforms, Economic and Social Progress in Latin America Report. Washington, D.C.: Johns Hopkins. 
Joulfaian, David, and Michael Marlow. 1990. Government Size and Decentralization: Evidence from Disaggregated Data. Southern Economic Journal 56 (4):1094-1102.

Marlow, Michael. 1988. Fiscal Decentralization and Government Size. Public Choice 56 (3):259-69.

Meltzer, Allan, and Scott Richard. 1981. A Rational Theory of the Size of Government. Journal of Political Economy 89 (5):914-27.

Milesi-Ferretti, Gian Maria, Roberto Perotti, and Massimo Rostagno. 2001. Electoral Systems and Public Spending. Working Paper 01/22. Washington, D.C.: International Monetary Fund.

Musgrave, Richard. 1959. The Theory of Public Finance: A Study in Public Economy. New York: McGraw-Hill.

Oates, Wallace. 1972. Fiscal Federalism. New York: Harcourt Brace Jovanovich.

- 1979. Lump-Sum Intergovernmental Grants Have Price Effects. In Fiscal Federalism and Grants-in-Aid, edited by P. Mieszkowski and W. Oakland, 23-30. Washington, D.C.: Urban Institute.

1985. Searching for Leviathan: An Empirical Study. American Economic Review 75:748-57.

1991. On the Nature and Measurement of Fiscal Illusion: A Survey. In Studies in Fiscal Federalism, edited by Wallace Oates, $431 \sim 48$. Brookfield, Vt.: Edward Elgar.

Organization of Economic Cooperation and Development (OECD). 1999. Taxing Powers of State and Local Government. OECD Tax Policy Studies No. 1. Paris: OECD.

Panizza, Ugo, 1999. On the Determinants of Fiscal Centralization: Theory and Evidence. Journal of Public Economics 74 (1):97-139.

Persson, Torsten, and Guido Tabellini. 1994. Does Centralization Increase the Size of Government? European Economic Review 38 (3-4):765-73.

_ 2000. Political Economics: Explaining Economic Policy. Cambridge, Mass.: MIT Press.

Quinn, Dennis. 1997. The Correlates of Change in International Financial Regulation. American Political Science Review 91 (3):531-51.

Rodden, Jonathan. 2002. The Dilemma of Fiscal Federalism: Grants and Fiscal Performance Around the World. American Journal of Political Science 46 (3):670-87.

- 2003. Hamilton's Paradox: The Promise and Peril of Federalism. Unpublished book manuscript, MIT, Cambridge, Mass.

Rodden, Jonathan, Gunnar Eskeland, and Jennie Litvack. 2003. Fiscal Decentralization and the Challenge of Hard Budget Constraints. Cambridge, Mass.: MIT Press.

Rodden, Jonathan, and Susan Rose-Ackerman. 1997. Does Federalism Preserve Markets? Virginia Law Review 83 (7): 1521-72.

Roubini, Nouriel, and Jeffrey Sachs. 1989. Political and Economic Determinants of Budget Deficits in the Industrial Democracies. European Economic Review 33 (5):903-33.

Rodrik, Dani. 1998. Why Do More Open Economies Have Bigger Governments? Journal of Political Economy 106 (5):997-1032.

Scharpf, Fritz, Bernd Reissert, and Fritz Schnabel. 1976. Politikverflechtung: Theorie und Empirie des kooperativen Föderalismus in der Bundesrepublik. Kronberg, Germany: Scriptor Verlag.

Stein, Ernesto. 1999. Fiscal Decentralization and Government Size in Latin America. Journal of Applied Economics 2 (2):357-91.

Taylor, Charles, and Michael Hudson. 1972. World Handbook of Political and Social Indicators, 2d ed. New Haven, Conn.: Yale University Press.

Treisman, Daniel. 2001. The Causes of Corruption: A Cross-National Study. Journal of Public Economics 76 (3):399-457.

Von Hagen, Jürgen. 1998. Budgeting Institutions for Aggregate Fiscal Discipline. Working Paper B011998. Bonn: Center for European Integration Research.

Weingast, Barry. 1995. The Economic Role of Political Institutions: Market-Preserving Federalism and Economic Development. Journal of Law, Economics, and Organization 11 (1):1-31.

Weingast, Barry, Kenneth Shepsle, and Christopher Johnsen. 1981. The Political Economy of Benefits and Costs: A Neoclassical Approach to Distributive Politics. Journal of Political Economy 89 (4):642-64. 
Wilson, John. 1986. A Theory of Interregional Tax Competition. Journal of Urban Economics 19 (3):296-315.

1999. Theories of Tax Competition. National Tax Journal 52 (2):269-304.

Winer, Stanley. 1980. Some Evidence on the Effect of the Separation of Spending and Taxing Decisions. Journal of Political Economy, 91 (1):126-40.

World Bank. 2000. World Development Indicators on CD-ROM. Washington, D.C.: World Bank.

Zodrow, George, and Peter Mieszkowski. 1986. Pigou, Tiebout, Property Taxation, and the Underprovision of Local Public Goods. Journal of Urban Economics 19 (3):356-70. 